\title{
DIVERSITY AND COMMUNITY STRUCTURE OF MACROALGAE AT KOH TAEN, HAAD KHANOM-MU KOH TALE TAI, MARINE NATIONAL PARK, NAKHON SI THAMMARAT PROVINCE, THAILAND
}

\author{
Anchana Prathep*, Anuchit Darakrai, Piyalap Tantiprapas, Jaruwan Mayakun, \\ Pimonrat Thongroy, Bongkot Wichachucherd, Sutinee Sinutok \\ Seaweed and Seagrass Research Unit, Centre for Biodiversity of Peninsular Thialand, \\ Department of Biology, Faculty of Science, Prince of Songkla University, \\ Hatyai. Songkhla. 90112. Thailand \\ e-mail: anchana.p@psu.ac.th
}

\begin{abstract}
The diversity and community structure of macroalgae at Koh Taen, Haad Khanom-Mu Koh Tale Tai, marine National Park, Nakhon Si Thammarat Province, Thailand were investigated from $1^{\text {st }} 5^{\text {th }}$ October 2005 (preliminary survey). Out of a total of 41 species: 15 species each of green and red algae, 9 species of brown algae and 2 species of blue green algae were found. In the area, subsequently four sites were established for monitoring. Quadrat sampling was employed to assess the abundance of macroalgae. In total sixty quadrats were monitored each month from October 2005 to April 2007. We report the variations of diversity and abundance of macroalgae among sites and seasons and speculate about what might cause such variations.
\end{abstract}

Keywords: Diversity, Community, Macroalgae, Koh Taen, Thailand

\section{INTRODUCTION}

The Macroalgae Diversity Group in the Japanese Society for Promotion of Science (JSPS) Multilateral Programs for Marine Science chose Talibong Island as a representative area of the Andaman Sea and Koh Samui as the representative of the Gulf of Thailand. The first phase of study has been completed and the diversity and community structure of macroalgae at Talibong have been published. More than eighteen species were found (Prathep and Tantiprapas, 2006). However, the Gulf of Thailand study site was changed to Koh Taen because Koh Samui has been greatly disturbed by the tourist industry and also because a report on the diversity of macroalgae at Samui has already been published (Mayakun and Prathep, 2005). It was therefore decided that Koh Taen was a more apnropriate study site.

The very first report of marine algal flora in Thailand was published in 1866 in "Die Preussische
Expedition nach Ost-Asien" (Martens, 1866), followed by "Flora of Koh Chang" (Schmidt, 19001916) and "List des algues du siboga" (Weber van Bosse, 1913-1928). Later in the 1970's there were a few studies of marine algae reported e.g. Egerod (1971, 1974, and 1975), Velasquez and Lewmanomont (1975), Lewmanomont (1976, 1978). A series of Gracilaria research have been reported by Lewmanomont (1994, 1995). The number of studies and publications on macroalgae in Thailand (Powtongsuk, 2000) and in Southeast Asian waters (Ogawa et al., 2003) have sharply declined. Only a few studies have been reported since the year 2000 (Aungtonya and Liao, 2002; Lewmanomont and Chirapart, 2004). In addition, recent studies of diversity, distribution and abundance of macroalgae in Southern Thailand has been increasing, providing more information about seaweed biodiversity in Thailand (Prathep, 2005; Mayakun and Prathep, 2005; Prathep and Tantiprapas, 2006; Prathep et al., 2007; Thongroy et al., 2007). 
In this report we document the results of our investigation on the diversity and community structure of macroalgae on a shallow coral reef of Koh Taen. The results add to the information about seaweed biodiversity in Thailand since the compilation by Lewmanomont et al., in 1995.

\section{MATERIALAND METHODS}

The monitoring of seaweed biodiversity and percentage cover started under the 'Biodiversity of Seaweed and Seagrass Program in South East Asia' in the "Japanese Society for Promotion of Science (JSPS) Multilateral Programs for Marine Science". Koh Taen, Nakhon Si Thammarat Province, was chosen as the monitoring site of Thailand because of its relatively pristine condition. Koh Taen is only 15 minutes away by long tail boat from Koh Samui. Both islands are similar in marine diversity and other physical and biological parameters. Koh Taen has also been proposed as a base for the 'Marine Biodiversity Initiative
Project' funded by BRT (Biodiversity Research and Training Program, Thailand) and TOTAL E\&P Thailand and TOTAL Foundation of France. The Khanom Marine Biodiversity Project provided information about diversity of many marine organisms, which some have been recently published (Putchakarn, 2007).

Preliminary surveys around the island during $1^{\text {st }}-5^{\text {th }}$ October 2005, showed that there was high diversity and abundance of macroalgae on the east coast of Koh Taen. Specimens were collected and brought back to the laboratory for identification. To study the community of macroalgae, sixty 0.5 $\mathrm{m} \times 0.5 \mathrm{~m}$ permanent plots, 15 plots at each site, were randomly set up at 3 different sites along the east coast and at 1 site on the west coast, (Fig. 1). Sites 1, 2, 3 and 4 all have sheltered sandy and rocky substrates, but site 4 is more exposed to the wave action during the Southwest monsoon. Each plot was marked using GPS, GARMIN GPS 76; and fluorescence tape was used to mark at all corners of each plot. The diversity and percentage

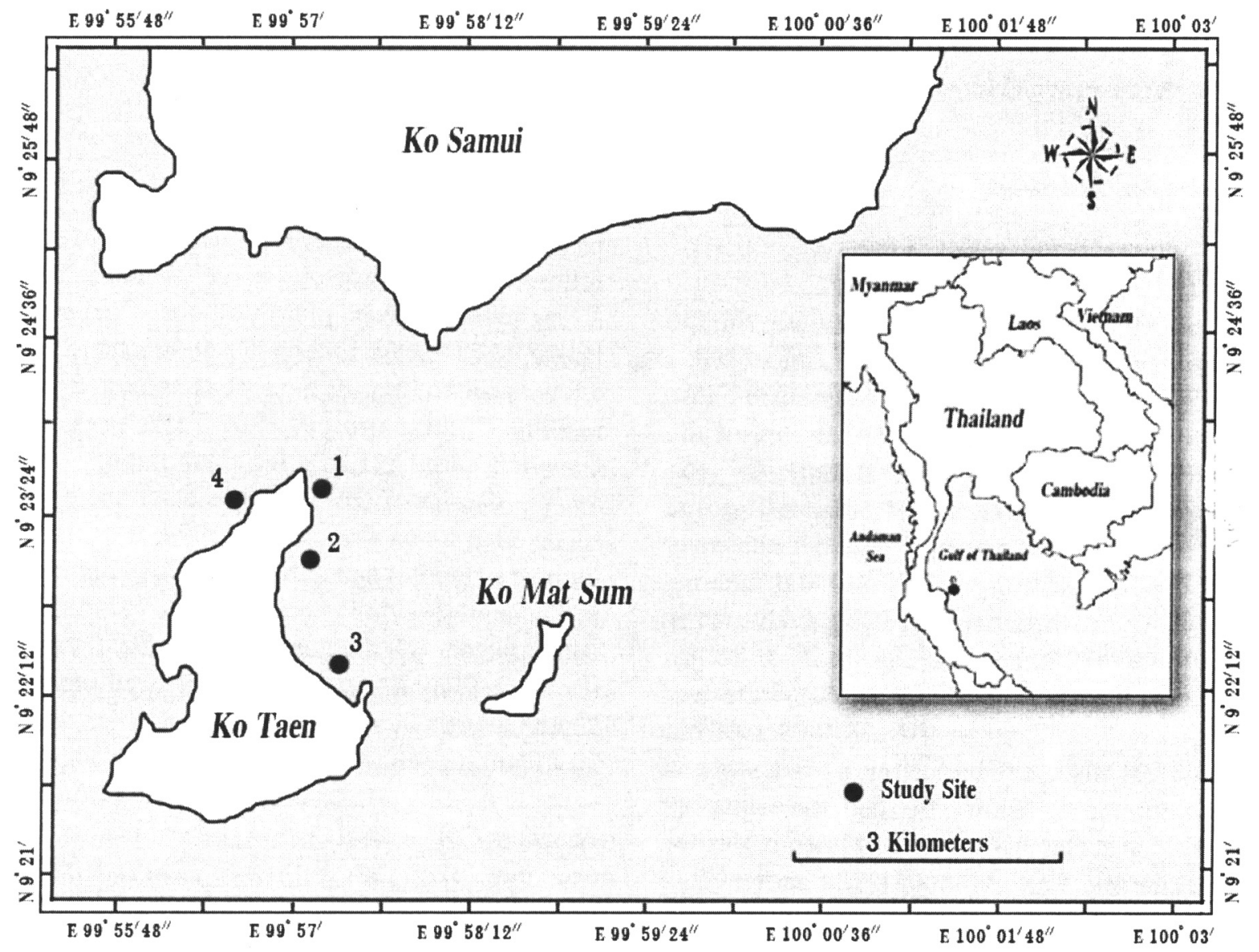

Figure 1. Sampling sites along Koh Taen, Haad Khanom-Mu Koh Tale Tai, Marine National Park, during October 2005-April 2007. 
cover of macroalgae at each plot were estimated at the sites from October 2005 to April 2007. The estimates of percentage cover followed the guidelines of Saito and Atobe (1970).

Koh Taen is influenced by the Southwest Monsoon from May-November which represents a rainy season and by the Northeast Monsoon from December-April, a dry season. Field collections were made in October 2005, May, July, October, December 2006 and April 2007. These collections covered the differences in seasons.

\section{Statistical Analysis}

Analyses of variance (ANOVA) were employed to test the effect of 1) sites and 2) seasons on percentage cover of macroalgae using STATISTICA version 6.0. If necessary, data were transformed to meet the assumptions of the parametric test. Friedman ANOVA was employed if there was no homogeneity of data after a series of transformations. Statistical results are based on the transformed analyses, but for clarity graphical output was based on the untransformed means.

\section{RESULTS}

A preliminary survey around Koh Taen showed a great diversity of macroalgae; a total of fortyone species were found: 15 species of Chlorophyta, 15 species of Rhodophyta, 9 species of Phaeophyta and 2 species of Cyanobacteria (Table 1). Later, however, other species (Chaetomorpha crassa, Cladophora sp., Udotea flabellum and Valonia sp.) were discovered in the monitoring plots.

There were variations in diversity and the communities of macroalgae among sites and seasons. The highest diversity was found at Site 2 in April 2007. Fourteen species of macroalgae (Table 2) were recorded. Gelidiella acerosa, Padina spp., Sargassum spp. and Turbinaria spp. occurred at all 4 sites during every month of collection. Bryopsis pennata, Cladophora sp., Struvea sp. occurred only once throughout the study. It was clear that there was greater species diversity during the dry season (December to May) than during the rainy months (May to November) at all sites.

The abundance of all species varied among sites and seasons. Many common species were significantly differing in percentage cover (Table 3). Sargassum spp and Turbinaria spp. were the two most dominant species. They covered the greatest areas at all 4 sites. The highest percentage cover of Turbinaria spp. was $42.33 \pm 2.67$ (mean \pm S.E.) in April 2007 at Site 1. The coverage of Turbinaria spp. also showed seasonal variations throughout the year with its lowest percentage cover in October 2005 and 2006, $7.67 \pm 1.76$ and $9 \pm 4.58$, respectively (Fig. 2a). Sargassum spp. also showed seasonal variation at all 4 sites. Because of the lengthy thallus (some fronds were greater than 2 meters in length) it covered a greater area than Turbinaria. The highest percentage cover of Sargassum. was $36.87 \pm 5.69$ in December 2006 at Site 3, the coverage then dropped at all 4 sites in April 2007 (Fig. 2b).

Padina spp., Gelidiella acerosa and Rhipidosiphon javensis were found at all sites. Although $G$. acerosa and $R$. javensis were small in size, they covered large areas at many sites. Gelidiella acerosa, with its $2-4 \mathrm{~cm}$ feathery long thallus, became dominant at Site 1, covering $28 \pm$ $4.76 \%$ of the area in July 2006 (Fig. 2c). Rhipidosiphon javensis, a fan-shaped green alga $2-3 \mathrm{~cm}$ in length, covered $10.67 \pm 4.55 \%$ of the area at Site 4 in December 2006 (Fig. 2d). Another macroalga, Laurencia nidifica, bloomed and covered a large area of $35.54 \pm 3.66 \%$ at Site 3 in April 2007(Fig. 2e). It is also notable that the dominance of one species was accompanied by a lesser coverage of another species occupying a same space. Such competitive interactions were clear in the cases of Sargassum spp. and Turbinaria spp.

\section{DISCUSSION}

The preliminary survey of October 2005, documented 7 more species at Koh Taen than at Koh Samui in 2003 (Mayakun and Prathep, 2005). However, the species composition of the shared species was different (Table 1). The differences between the number of species might be because of the number of sampling sites. Only 5 sites were sampled at Koh Samui and a total of 8 sites were sampled along coastal lines of Koh Taen at both sides. Also, Koh Samui is known for its tourist industrial, which could disturb the marine life. Field collection efforts, human and natural disturbances could also play important roles in making an accurate assessment of the number of species.

Although the number of species found was not greatly different from species reported from 


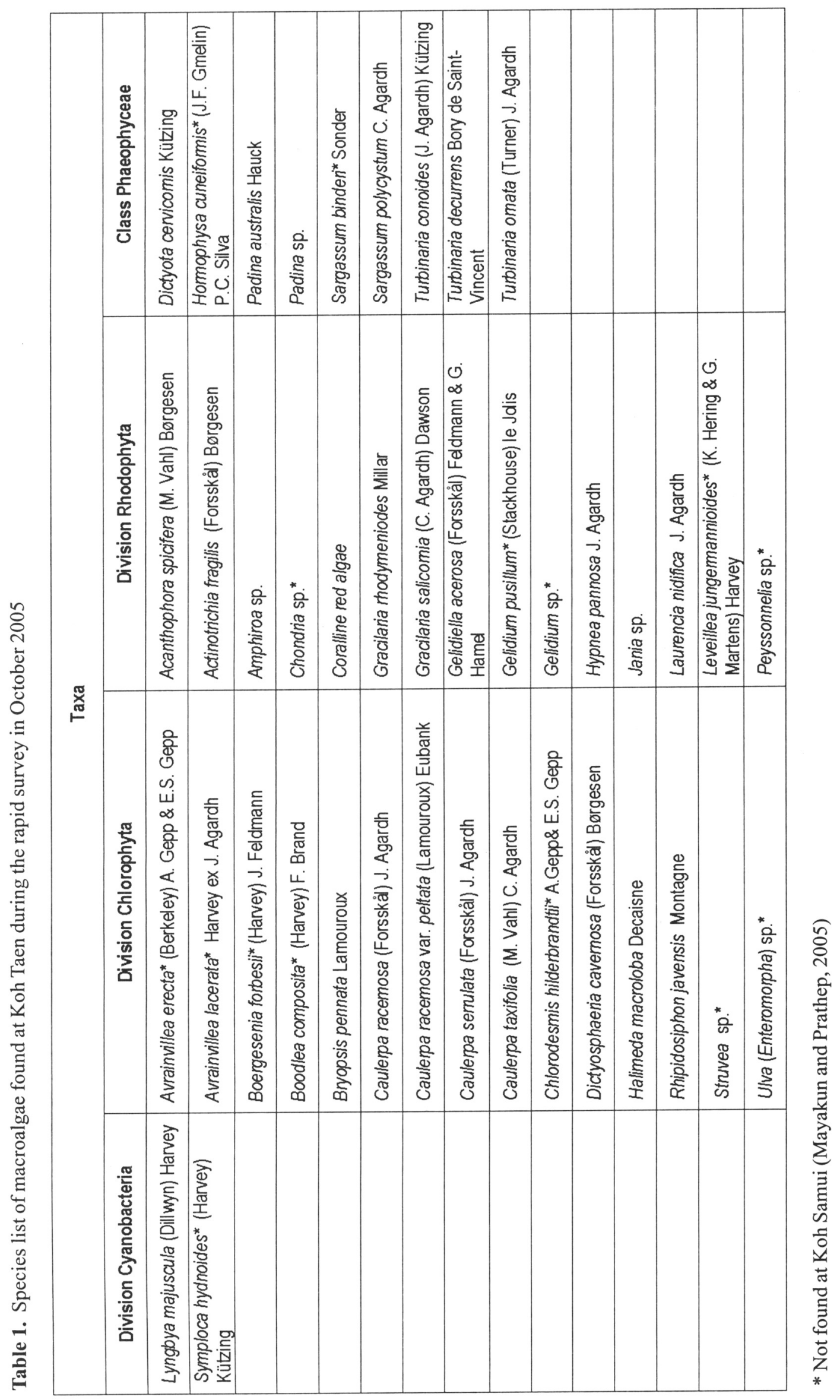




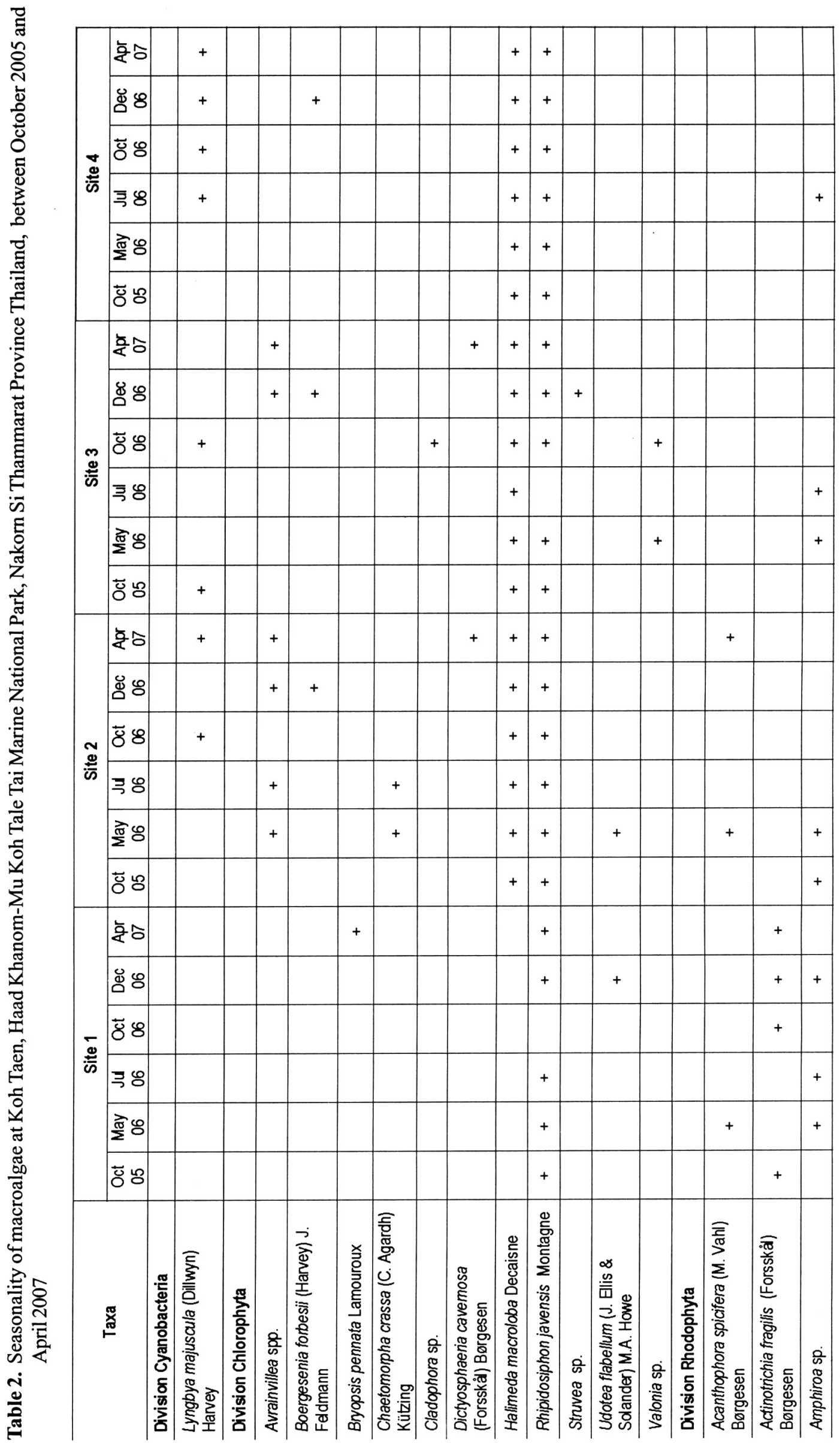




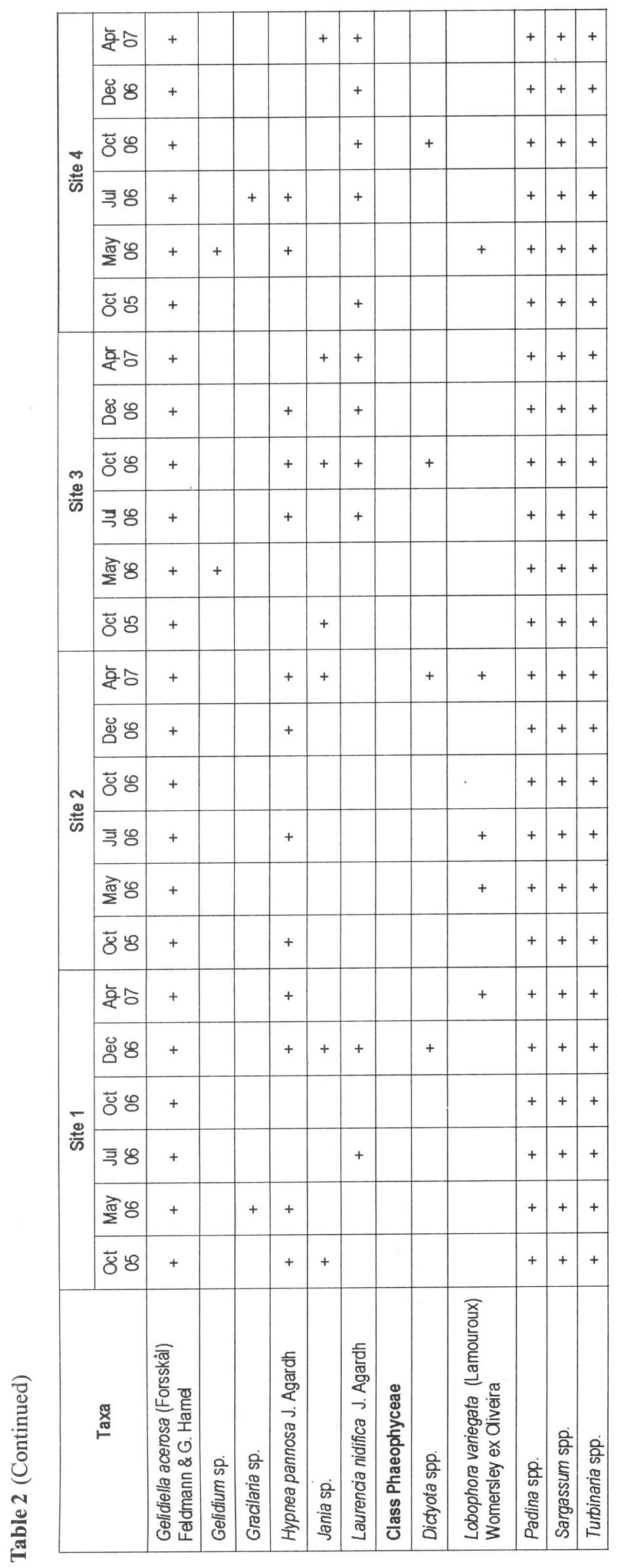


Table 3. Summary of Friedman ANOVA test on the effects of sites and seasons on percentage coverage of some species at Koh Taen, Haad Khanom-Mu Koh Tale Tai Marine National Park, Nakorn Si Thammarat Province, Thailand, between October 2005 and April 2007.

\begin{tabular}{|l|r|r|r|c|}
\hline & N & df & Chi-square & P \\
\hline Gelidiella acerosa & 12 & 23 & 102.13 & $<0.001$ \\
\hline Laurencia nidifica & 12 & 23 & 104.41 & $<0.001$ \\
\hline Padina spp. & 12 & 23 & 75.49 & $<0.001$ \\
\hline Rhipidosiphon javensis & 12 & 23 & 53.79 & $<0.001$ \\
\hline Sargassum spp. & 12 & 23 & 69.29 & $<0.001$ \\
\hline Turbinaria spp. & 12 & 23 & 109.39 & $<0.001$ \\
\hline
\end{tabular}

$\mathrm{N}=$ number of samplings

$\mathrm{df}=$ degrees of freedom

$\mathrm{P}=$ level of significant
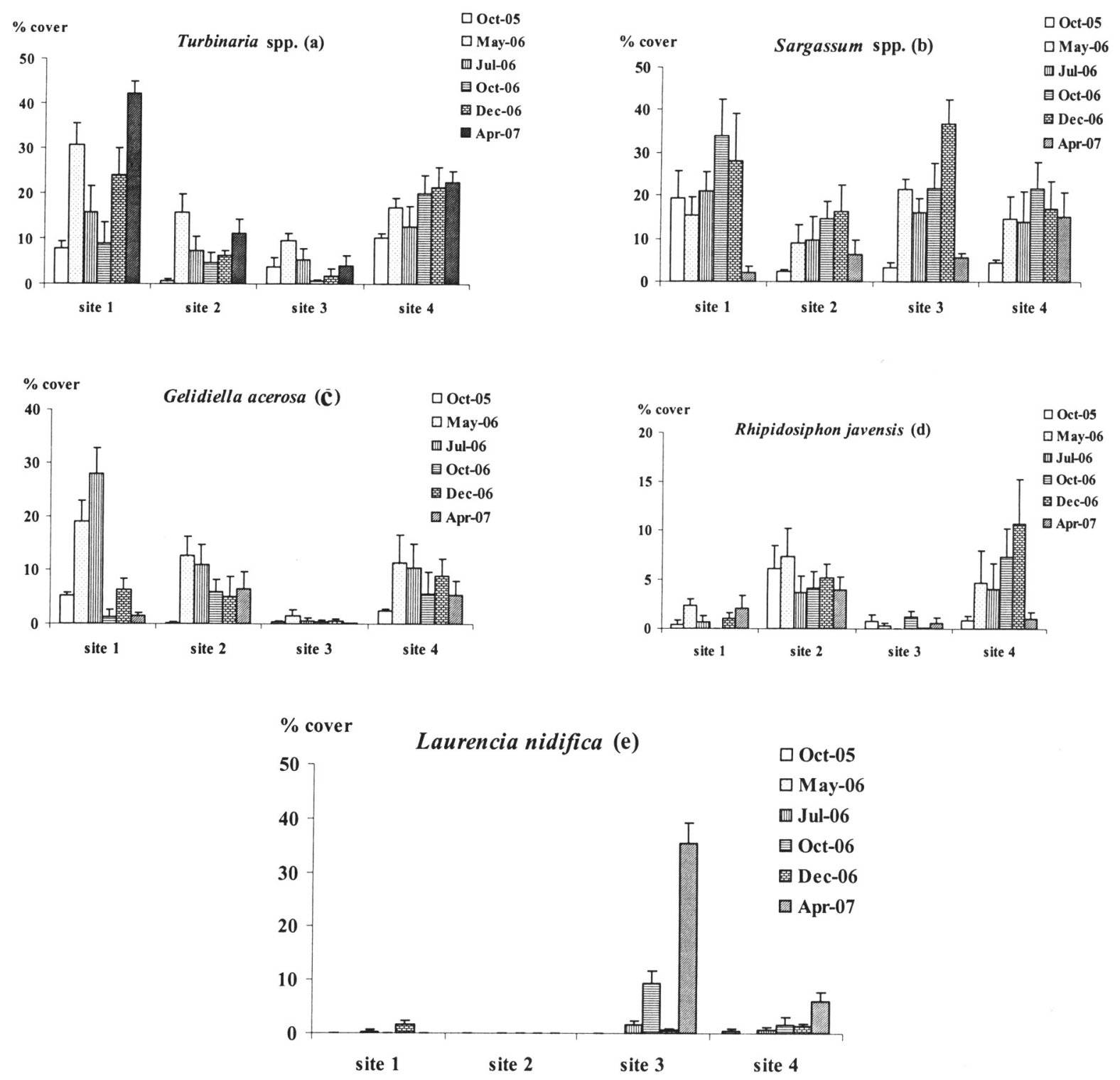

Figure 2. Distribution of macroalgal percentage cover of common species (mean \pm S.E.) at different sites; (different y-axis scales). 
Phuket along the Andaman coast, where 52 species (Thongroy et al., 2007) were reported, the species composition was different in the Gulf of Thailand. An intensive study of species diversity and distribution of macroalgae in Southern Thailand would help us to better understand the distribution patterns of macroalgae between the Indian and the Pacific Oceans. On a smaller scale, a set of islands in the Gulf of Thailand such as Koh Taen, Samui and some other neighboring islets, could be used as a model to test the dispersal abilities of macroalgae.

Similar to other studies, a greater of species were found during the dry season (Mayakun and Prathep, 2005; Prathep, 2005; Prathep and Tantiprapas, 2006; Thongroy et al., 2007). This might be because of greater wave action during the rainy season, which destroys and removes fragile species such as Bryopsis pennata, Cladophora sp. and Struvea sp. That might be the reason why these species were only observed once during our study. Wave action could also stir up the sediments, covering the small, less abundant species such as Dictyosphaeria cavernosa, Gelidium sp. and Valonia sp, which were absent during the rainy seasons. Wave action can also wash away or snap fronds off the common dominant species such as Padina spp. and Turbinaria spp. as reported by Parthep and Tantipapas (2006) and Prathep et al., (2007). This causes a decrease in coverage. However, this does not occur with, Sargassum spp. and Laurencia nidifica, two other dominant species. Sargassum spp. coverage dropped sharply in the dry season, while Laurencia nidifica bloomed and became dominant. Further investigations on population ecology including studies of growth, reproduction and recruitment would allow us to better understand these phenomenons, which are less well known in the tropics than in the temperate waters (compare Ang, 1991; Aberg, 1992; Kendrick and Walker, 1995).

Interactions between species are clearly shown in this study. The dominance of Sargassum spp. during October 2006 at Site 1 limited the coverage of Turbinaria spp. When Turbinaria spp. became dominant, the coverage of Sargassum spp. decreased in May 2006. The interaction between small benthic species such as Gelidiella acerosa and Rhipidosiphon javensis, seems to indicate competition for space. Studies of such competitive interactions would help us better understand the ecological roles of seaweed species in tropical communities as already more broadly studied in temperate shores (Guimaraens et al., 1996; Creed et al., 1998; Choi and Norton, 2005).

Koh Taen has developed into a tourist destination for one-day snorkeling trips where tourist also feed the coral fishes, some of which are principal grazers of seaweeds. The development of Koh Taen is at the beginning stage, but already great damage to the corals has occurred. Increase in sedimentation and changing water circulation related to an artificial canal to allow long tail boats to reach the shore. The tourist activities such as fish feeding, snorkeling and trampling on the reefs influences the diversity, population and community of marine organisms as shown in many studies (Kay and Liddle, 1989; Hawkins and Roberts, 1993; Rogers et al., 2003). Further experiments on the effects of sedimentation and trampling on the populations and their effect on growth and reproduction and species diversity, species composition and community structure would allow us to better understand the effects of these stresses on the marine organisms. Good baseline information is necessary in order to advise about management of natural resources and to enforce the already established laws for coastal development or ecotourism in Southeast Asia.

Acknowledgements. We are very grateful for all the support of the members of the "Seaweeds and Seagrass Research Unit", Centre of Biodiversity in Southern Peninsular Thailand, PSU, Thailand. Thanks to Professor Hisao Ogawa and JSPS providing traveling grant and support; Professor Larry B. Liddle helped to improve the manuscript. This work was supported by the TRF/BIOTEC Special Program for Biodiversity Research and Training grant BRT R_149020, TOTAL E\&P Thailand and TOTAL Foundation of France.

\section{REFERENCES}

Aberg, P. 1992. A demographic study of two populations of the seaweed Ascophyllum nodosum. Ecology, 73(4): 1473-1487.

Ang, P.O. 1991. Natural dynamics of a Fucus distichus (Phaeophyceae, Fucales) population: reproduction and recruitment. Mar. Ecol. Prog. Ser., 78: 71-85. 
Aungtonya, C. and L.M. Liao. 2002. Marine flora (algae and seagrasses) in the reference collection of the Phuket Marine Biological Center, Thailand. Phuket Mar. Biol. Cent. Res. Bull., 64: 65-80.

Choi, H.G. and T.A. Norton. 2005. Competition and facilitation between germlings of Ascophyllum nodosum and Fucus vesiculosus. Mar Biol., 147(2): 525-532.

Creed, J.C., J.M. Kain and T.A. Norton. 1998. An experimental evaluation of density and plant size in two large brown seaweeds. J. Phycol., 34(1): 39-52.

Egerod, L. 1971. Some marine algae from Thailand. Phycologia 10: 121-142.

Egerod, L. 1974. Report of the marine algae collected on the Fifth Thai-Danish Expedition of 1966, Chlorophyceae and Phaeophyceae. Bot. Mar., 17: 160-157.

Egerod, L. 1975. Marine algae of the Andaman Sea coast of Thailand: Chlorophyceae. Bot. Mar., 18: 41-66.

Guimaraens, M.A., C.A. Coimbra, and R. Coutinho. 1996. Modeling competition between Laurencia obtusa (Ceramiales, Rhodophyta) and Hypnea spinella (Gigartinales, Rhodophyta) at Cabo Frio Island, Rio de Janeiro, Brazil. Hydrobiologia, 326-327(1): 273 276.

Hawkins, J.P. and C. M. Roberts. 1993. Effects of recreational scuba diving on coral reefs: trampling on reef-flat communities. J. Appl. Ecol., 30(1): 2530 .

Kay, A.M. and M.J. Liddle. 1989. Impact of human trampling in different zones of a coral reef flat. Environ. Manage., 13(4): 509-520.

Kendrink, G.A. and D.I. Walker. 1995. Dispersal of propagules of Sargassum spp. (Sargassaceae: Phaeophyta) observations of local patterns of dispersal and consequences for recruitment and population structure. J. Exp. Mar. Biol. Ecol., 192(2): 273-288.

Lewmanomont, K.1976. Algal flora of the mangrove areas. Research report, Faculty of Fisheries, Kasetsart University. (in Thai).

Lewmanomont, K. 1978. Some edible algae of Thailand. Kasetsart J., 12: 119-129 (in Thai).

Lewmanomont, K. 1994. The species of Gracilaria from Thailand. In: IA.Abbott (ed). Taxonomy of Economic Seaweeds: With Reference to Some Pacific Species. Vol. IV: California Sea Grant College, Univ. Calif. La Jolla, California: 135-148.

Lewmanomont, K. 1995. Gracilaria urvillei (Montagne) Abbott: A new record for Thailand. In: IA.Abbott (ed). Taxonomy of Economic Seaweeds: With
Reference to Some Pacific Species. Vol. V:California Sea Grant College, Univ. Calif. La Jolla, California: 223-226

Lewmanomont, K. and A. Chirapart. 2004. Additional records of Gracilaria from Thailand. In: (I.A. Abbott and K.J. McDermid, eds.): Taxonomy of economic seaweeds with reference to the Pacific and other locations. Vol. IX. California Sea Grant College, University of CA at La Jolla: 201-210.

Lewmanomont, K., L. Wongrat, and C. Supanwanid. 1995. Algae in Thailand. Integrated Promotion Technology Co., Ltd. Thailand: 334 pp.

Martens, GV. 1866. Die Preussiche Expedition nach OstAsien. Not. Theil. Dir Tang, K. Geheime, Berlin.

Mayakun, J. and A. Prathep. 2005. Seasonal variations in diversity and abundance of macroalgae at Samui Island, Surat Thani Province, Thailand. Songklanakarin J. Sci. Technol., 27: 653-663.

Ogawa, H., N. Nanba, T. Ajisaka, R. Terada, S Kawaguchi and H. Kawai. 2003. Scientific publications on macroalgae and seagrasses from Southeast Asian Waters marine biological journals and books from 1990-2003. Proceedings of the $1^{\text {st }}$ Oceanography, Chaingmai, 14-16, 2003: 178-181.

Powtongsook, S. 2000. Utilisation of algae: a research and development potential in Thailand. Chulalongkorn University Press, Bangkok: 356 pp.

Prathep, A. 2005. Spatial and temporal variations in diversity and percentage cover of macroalgae at Sirinart Marine National Park, Phuket Province, Thailand. ScienceAsia, 31:225-233.

Prathep, A. and P. Tantiprapas. 2006. Preliminary report on diversity and community structure of macroalgae before and after the 2004 Tsunami at Talibong Island, Trang Province, Thailand. Coastal Marine Science, 30: 189-195.

Prathep, A., B. Wichachucherd, and P. Thongroy. 2007. Spatial and temporal variation in density and thallus morphology of Turbinaria ornata in Thailand. Aqua. Bot., 86:132-138.

Putchakarn, S. 2007. Species diversity of marine sponges dwelling in coral reefs in Had KhanomMu Ko Thale Tai National Park, Nakhon Si Thammarat Province, Thailand. J. Mar. Biol. Assoc. UK., 87:1635-1642.

Rodgers, K., E.Cox, and C. Newtson. 2003. Effects of mechanical fracturing and experimental trampling on Hawaiian corals. Environ. Manage., 31(3): 377384.

Saito, Y and S. Atobe. 1970. Phytosociological study of intertidal marine algae I. Usujiri Benten-Jima, Hokkaido. Bull. Fac. Fish. Hokkaido Univ., 21(2): $37-69$. 
Schmidt, J. 1900-1916. Flora of Koh Chang. Contributions to the Knowledge of the Vegetation in the Gulf of Siam. Bianco Luco, Copenhagen.

Thongroy, P., L. M. Liao, and A. Prathep. 2007. Diversity, abundance and distribution of macroalgae at Sirinart Marine National park, Phuket Province, Thailand. Bot. Mar., 50(2): 88-96.
Velasquez, G.T. and Lewmanomont, K. 1975. A checklist on the study of the benthic marine algae of Thailand. Kasetsart U. Fish. Research Bull., 8: 125.

Weber van Bosse, A. 1913-1928. List des algues du Siboga. Siboga Epeditie Monogr. E. J. Brill, Leiden 59: 1-533. 